\title{
Maintaining of the Spotted Wing Drosophila suzukii (Matsumura) (Diptera: Drosophilidae) Wild Colony on a Suitable Artificial Diet
}

\author{
Hanife Genc
}

ÇOMÜ Ziraat Fakültesi, Tarımsal Biyoteknoloji Bölümü, 17100/Çanakkale

Sorumlu yazar: hgenc@comu.edu.tr

Geliş Tarihi: 16.09.2019

Kabul Tarihi: 12.11.2019

\begin{abstract}
Laboratory rearing and adaptation of pest insects have important features to enhance integrated pest management programs. The spotted wing drosophila, Drosophila suzukii (Matsumura), is newly introduced pest in Turkey and first reported in 2016, damages important fruit crops. Five agar-based larval diets for laboratory rearing of the spotted wing drosophila were tested. Biological performances were determined based on development times of larva and pupa, number of survival and weights of larva and pupa. Diet II was the best,

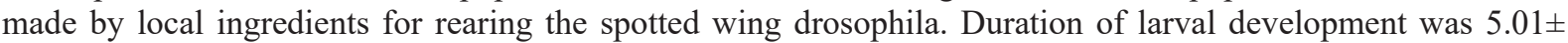
$0.14 \mathrm{~d}$ with $95 \%$ of the larval survival. The number of pupal survival was higher than larvae reared on control diet. The spotted wing drosophila were reared on Diet II successfully for 10 consecutive generations.
\end{abstract}

Keywords: Spotted wing Drosophila, Drosophila suzukii, artificial diet, rearing

\section{Yabanil Drosophila suzukii (Matsumura) (Diptera: Drosophilidae) kolonisinin Uygun Bir Yapay Besinde Üretilmesi $\ddot{O}_{z}$}

Böceklerin laboratuvarda üretilmesi ve adaptasyonu entegre zararlı mücadelesi programlarının önemli özelliklerindendir. Kanadı noktalı drosophila, Drosophila suzukii (Matsumura), Türkiye'de istilacı bir türdür, ilk kez 2016 yılında tespit edilmiştir ve önemli meyve ürünlerinde zararlıdır. Agarla katılaştırılmış beş larva diyeti kanadı noktalı drosophila için test edildi. Larva ve pupa gelişme süreleri, canlı kalma oranları ve ağırlıkları belirlenerek biyolojik performansları tespit edildi. Yerel malzemelerle hazırlanan Diet II, kanadı noktalı drosophila'nın beslenmesinde en iyi sonuçları verdi. Kontrol diyet ile karşılaştırıldığında, larva gelişme süresi $5.01 \pm 0.14$ gün, \% 95 larva canlılığı ve yüksek pupa canlılık oranı elde edildi. Kanadı noktalı drosophila Diet II üzerinde başarılı olarak devam eden 10 nesil boyunca üretildi.

Anahtar Kelimeler: Kanadı noktalı Drosophila, Drosophila suzukii, yapay besiyeri, yetiştirme

\section{Introduction}

The spotted wing drosophila, Drosophila suzukii (Matsumura) (Diptera: Drosophilidae) is an invasive pest and reported in Erzurum, Turkey in 2016 (Orhan et al., 2016). It is a serious economic pest and originated in Southeast Asia in regions (Kanzawa, 1939) then in 2008, first reported in European countries in Spain, Italy and at the same time in North America (Raspi et al., 2011; Calabria et al., 2012). After 2008, D. suzukii was widely distibuted in worlwide. It is a polyghagous pest, having a wide range of small fruits, stone fruits, ornamental and wild fruits and reported 20 plant families (Lee et al., 2016; Kenis et al., 2016; Cini et al., 2012). Larvae damage the fruit crops, feeding inside the ripening fruits and reducing yield and marketable value of the fruits. To control D. suzukii, although cultural, biological, mechanical and chemical strategies were developed, insecticides are commonly used in the field and orchards (Beers et al., 2011)

Understanding of pest's nutrional physiology is a key factor to guide laboratory maintaince and adaptation. Insects generally require the same nutritional components as larger animals. Proteins and amino acids are important for development and growth. Carbohydrates are the main energy source. Lipids are either convert from carbohydrates or freely taken, especially polyunsaturated fatty acids and sterols are important to insects. Vitamins are important as cofactors and trace amount of minerals is needed for insect's diet (Nation, 2016). Overall the balance of the nutritional components 
is crucial for biological performance (Nation, 2016; Schlesener et al., 2018). Various nutritive and bulking artificial diet components usually costly and some may have to be imported abroad so replacing of these components by local market products would be favorable. Knowledge of larval feeding preference and behaviour can enhance management of $D$. suzukii. The goal of the presented study was to report the biological parameters on tested different artificial diets and to report a suitable larval diet for continuous laboratory rearing of the spotted wing drosophila.

\section{Material and Methods}

\section{Laboratory Rearing Procedures}

Fly culture was established from infested strawberries, collected in Yenice County, Çanakkale during the summer of 2018. Adults were allowed to lay eggs on strawberries, placed in plastic cups $(250 \mathrm{ml})$ under a layer of paper tissue and covered with a chiffon in controlled laboratory conditions, at $24 \pm 1{ }^{\circ} \mathrm{C}, 60 \%$ relative humidity and $18: 6$ (L:D) photoperiod. After the laboratory colony was maintaned on fruits, a random number of adults were placed to $25 \mathrm{ml}$ of centrifuge tubes containing about $20 \mathrm{ml}$ of Diet I, described by Schlesener et al. (2017) and covered with cotton balls.

To obtain eggs for the experiments, a thin layer of artificial diet was poured into a petri dish $(4 \mathrm{~cm}$ in diameter) and used as a lid for centrifuge tubes. Then the centrifuge tubes were placed upside down to collect adults on the diet. A week old adults were let to lay eggs for an hour, then lids were changed with the new one. The laid eggs were collected with a $0.3 \%$ propionic acid solution and lined with moistened black filter paper in a petri dish and kept until hatching (Fig. 1). The eggs were observed twice a day under the microscope to determine development time.
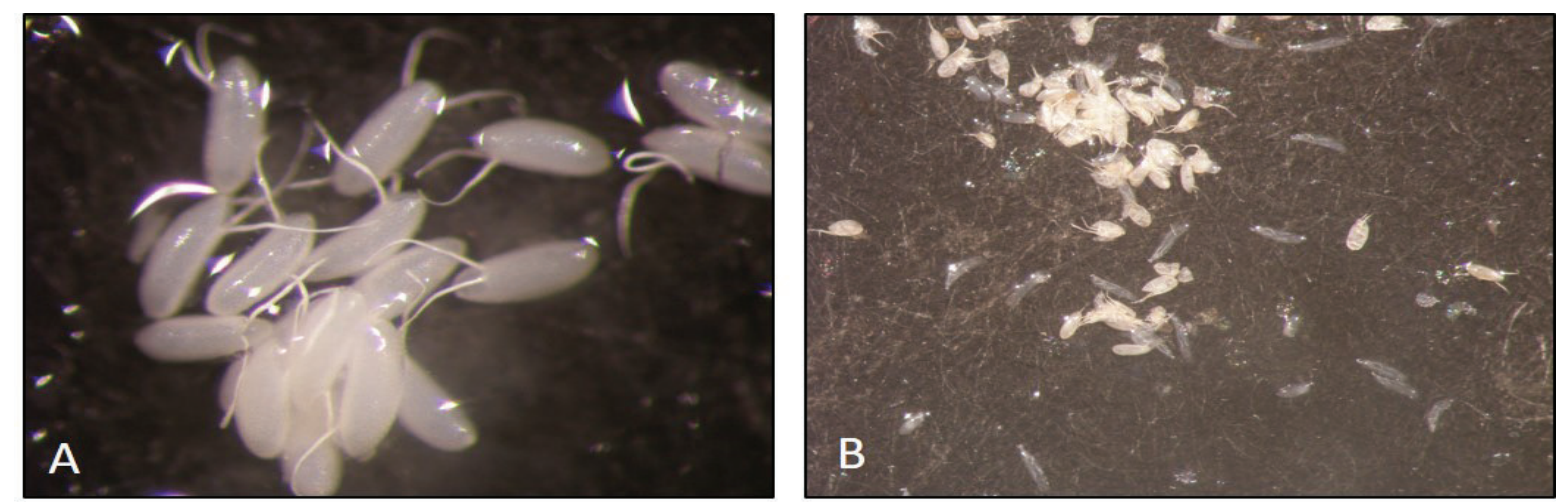

Fig. 1. A view of Drosophila suzukii eggs (A) and newly hatched eggs and neonates (B)

Newly hatched 100 larvae were collected on a piece of wetted black filter paper with a camelhair brush within $2 \mathrm{~h}$ of hatching then transferred to petri dish $(6 \mathrm{~cm}$ diameter) having $15 \mathrm{~g}$ of tested diets (Fig. 2). Each diet was tested on petri dishes, having a hundred of first instar, and 5 petri dishes were used considering as 5 replicates. Larval development was monitored daily under a microscope. When larvae completed their development, they were transferred to a bigger containers and white filter paper $(2 \times 7 \mathrm{~cm})$ placed into the diet for mature larvae to walk on before pupation. Pupae were collected with soft forceps after $2 \mathrm{~d}$. The biological parameters were evaluated for each tested diet such as the durations (days), the number of pupae and adults, the viability (\%) and weights (mg). The tested artificial diets and quantities of all ingredients were given in Table 1. All diet components were supplied from a local market (Çanakkale, Turkey). 


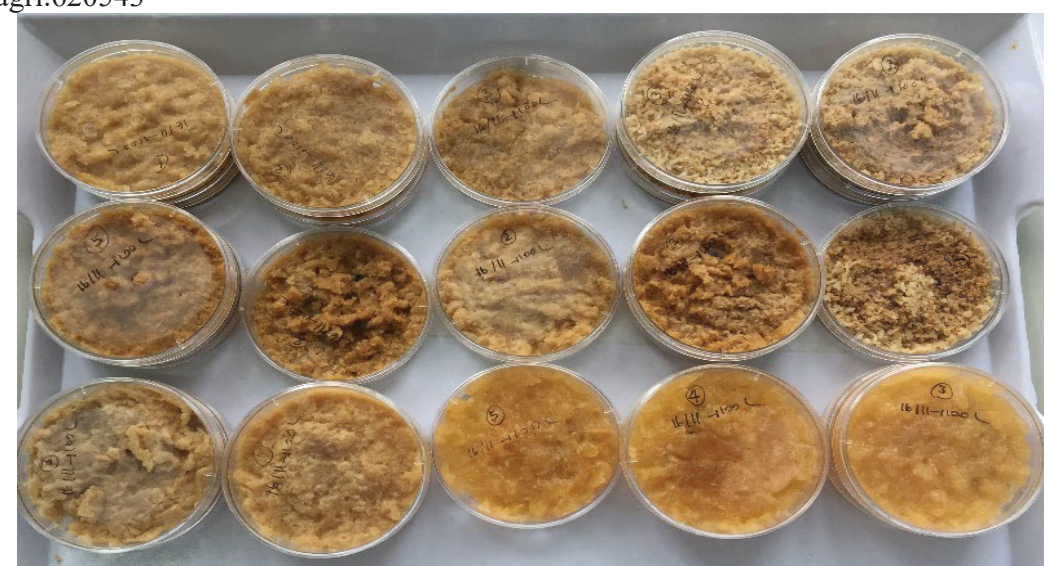

Fig. 2. A view of transferred larvae to tested artificial diets for Drosophila suzukii

\section{Preparation of Artificial Diets}

Diet I was described previously by Schlesener et al. (2017), Diet IV was known as standard $D$. melanogaster diet. The other diets were formulated using local basic ingredients for this study (Table 1). The larval medium was prepared fresh as follows: add $2 / 3$ of distilled hot water to the cornmeal and leave it for 10 min by mixing, boiled $1 / 3$ of the water then add agar and kept boiling for 5 min. Add other ingredients to the hydrated corn meal mixture and mixed them thoroughly then add the water-agar mixture. After the solution was cool down around $60{ }^{\circ} \mathrm{C}$, then propionic acid and methyl paraben were added before pouring the media into petri dishes or glass bottles. Diets were kept at $25^{\circ} \mathrm{C}$ for about $2 \mathrm{~h}$ then at $4^{\circ} \mathrm{C}$ until used.

\section{Statistical Analyses}

Descriptive statistics of the data were calculated as mean values \pm standard error (SE). The differences among diets were determined by analysis of variance (ANOVA). The LSD test was used to separate the means $(P=0.05$ level $)$.

Table 1. Ingredients of tested artificial diets for Drosophila suzukii in the laboratory

\begin{tabular}{|c|c|c|c|c|c|}
\hline Diet Components & $\begin{array}{c}\quad \text { Diet I } \\
\text { or Control } \\
\text { (Schlesener } \\
\text { et al.2017) }\end{array}$ & $\underline{\text { Diet II }}$ & $\underline{\text { Diet III }}$ & $\begin{array}{l}\text { Diet IV } \\
\text { (*standard } D . \\
\text { melanogaster } \\
\text { diet) }\end{array}$ & $\underline{\text { Diet } V}$ \\
\hline Water (ml) & 250 & 250 & 250 & 250 & 500 \\
\hline $\operatorname{Agar}(g)$ & 2 & 2 & 2 & 2 & 6 \\
\hline Brewers Yeast $(\mathrm{g})$ & 10 & - & 5 & 9.5 & 10 \\
\hline Corn Meal (g) & 20 & - & - & 19 & 10 \\
\hline Refined Sugar (g) & 25 & 25 & 5 & - & 10 \\
\hline Propionic acid (ml) & 0.75 & 0.75 & 0.75 & - & 4 \\
\hline Methyl paraben $(10 \%)(\mathrm{ml})$ & 2 & 2 & 2 & - & 1.5 \\
\hline Bean flour $(\mathrm{g})$ & - & 10 & - & 3.75 & - \\
\hline Chickbean Flour (g) & - & 10 & - & - & - \\
\hline Dry yeast (g) & - & 10 & - & - & - \\
\hline Wheat germ $(\mathrm{g})$ & - & 5 & - & - & - \\
\hline Wheat bran (g) & - & 5 & - & - & - \\
\hline Banana $(\mathrm{g})$ & - & - & 55 & - & - \\
\hline Molasses (ml) & - & - & - & 25 & - \\
\hline Persimmon $(\mathrm{g})$ & - & - & - & - & 100 \\
\hline
\end{tabular}

* https://bdsc.indiana.edu/information/recipes/molassesfood.html

\section{Results and Discussion}

Development time of larvae considering days from egg to pupation is an important indicator for a successful larval diet composition. The tested artificial diets were about as good as the control diet (Schlesener et al., 2017), but minor significant variations occurred in evaluated biological 
ÇOMÜ Zir. Fak. Derg. (COMU J. Agric. Fac.)

2019: 7 (2): 307-312

ISSN: $2147-8384$ / e-ISSN: 2564-6826

doi: $10.33202 /$ comuagri.620543

parameters (Table 2). The study was first performed into plastic petri dishes to screen the optimum diet formulation and provide the small scale laboratory colony (Fig. 3). Newly hatched larvae started feeding on agar based diets and high competition was usually occurred after $4^{\text {th }} \mathrm{d}$. Then strips of filter paper $(2 \times 7 \mathrm{~cm})$ were placed into petri dishes to let the larvae walked off the diets for pupation also to provide shelter to the larvae (Fig. 3). Completion of larval stages were $5.01 \pm 0.14 \mathrm{~d}$ on Diet II and $5.04 \pm 0.29 \mathrm{~d}$ on Diet III which were not significantly different from each other. Larval duration was $6.01 \pm 0.72 \mathrm{~d}$ on Diet I, $6.35 \pm 1.06 \mathrm{~d}$ on Diet IV and $6.96 \pm 0.93 \mathrm{~d}$ on Diet V (Table 2). The shortest pupal duration was $4.41 \pm 0.53 \mathrm{~d}$ on Diet V then $4.62 \pm 0.52 \mathrm{~d}$ on Diet III and $4.68 \pm 0.51 \mathrm{~d}$ on Diet II respectively. Among the diets, the number of harvested pupae $(59.5 \pm 12.12)$ and the number of adult emergence (37 \pm 18.12$)$ were the lowest on Diet IV (Table 2). Besides, the control diet allowed slightly greater pupal weight, overall evaluated parameters were compared, Diet II and then Diet III had a good consistency to rear the spotted wing drosophila larvae in the laboratory.
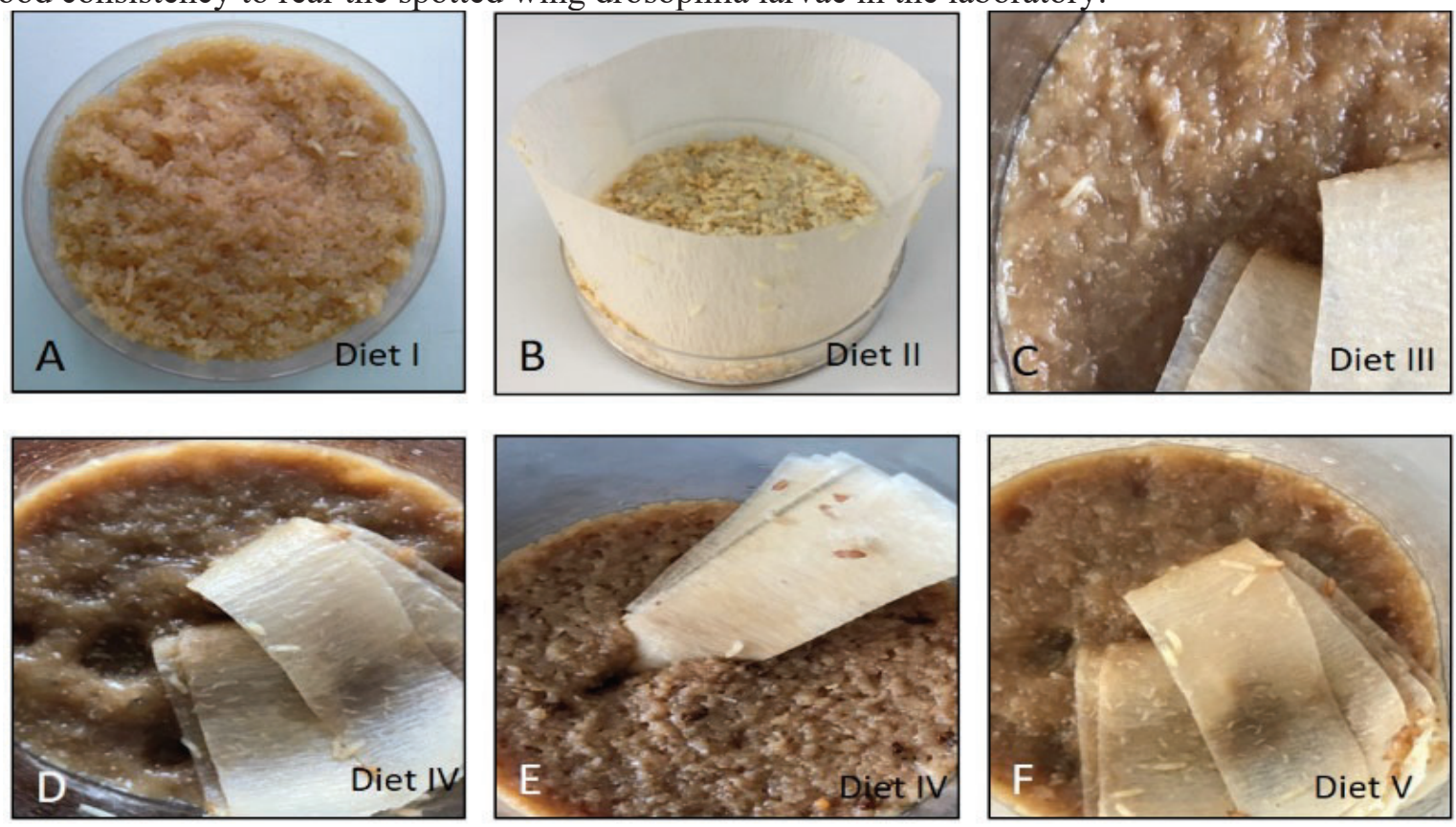

Fig. 3. A view of larval feeding on tested different diets into petri dishes

Table 2. Biological parameters of Drosophila suzukii rearing on five different larval diets (Mean $\pm \mathrm{SE}$ )

\begin{tabular}{lccccc}
\hline Parameters & \multicolumn{5}{c}{ Diet Types } \\
\hline & Diet I & Diet II & Diet III & Diet IV & Diet V \\
Larval duration (day) & $6.01 \pm 0.72 \mathrm{~B}$ & $5.01 \pm 0.14 \mathrm{~A}$ & $5.04 \pm 0.29 \mathrm{~A}$ & $6.35 \pm 1.06 \mathrm{C}$ & $6.96 \pm 0.93 \mathrm{D}$ \\
Pupal duration (day) & $5.06 \pm 0.56 \mathrm{C}$ & $4.68 \pm 0.51 \mathrm{~B}$ & $4.62 \pm 0.52 \mathrm{~B}$ & $5.09 \pm 0.57 \mathrm{C}$ & $4.41 \pm 0.53 \mathrm{~A}$ \\
No. of pupae & $74.8 \pm 4.86 \mathrm{~B}$ & $74.2 \pm 4.96 \mathrm{~B}$ & $78.4 \pm 7.53 \mathrm{~B}$ & $59.5 \pm 12.12 \mathrm{~A}$ & $71.8 \pm 2.68 \mathrm{~B}$ \\
No. of adult & $47.6 \pm 7.63 \mathrm{~A}$ & $62 \pm 7.64 \mathrm{~B}$ & $61 \pm 4.18 \mathrm{~B}$ & $37 \pm 18.12 \mathrm{~A}$ & $60.2 \pm 5.97 \mathrm{~B}$ \\
No. of female & $23.4 \pm 6.10 \mathrm{AB}$ & $31.6 \pm 5.22 \mathrm{D}$ & $24.4 \pm 1.67 \mathrm{BC}$ & $16.25 \pm 8.57 \mathrm{~A}$ & $31 \pm 3.31 \mathrm{CD}$ \\
No. of male & $24.2 \pm 3.42 \mathrm{AB}$ & $30.4 \pm 6.87 \mathrm{BC}$ & $36.6 \pm 3.36 \mathrm{C}$ & $20.75 \pm 10.46 \mathrm{~A}$ & $29.2 \pm 3.27 \mathrm{BC}$ \\
Larval survival (\%) & $68.77 \pm 5.37 \mathrm{C}$ & $95 \pm 8.11 \mathrm{~A}$ & $82.7 \pm 8.31 \mathrm{~B}$ & $69.52 \pm 3.98 \mathrm{C}$ & $91.1 \pm 7.15 \mathrm{~A}$ \\
Pupal recovery (\%) & $64.24 \pm 13.90 \mathrm{~A}$ & $84.9 \pm 11.97 \mathrm{~B}$ & $78.02 \pm 3.87 \mathrm{AB}$ & $60.73 \pm 26.24 \mathrm{~A}$ & $83.88 \pm 8.47 \mathrm{~B}$ \\
Mature larva (mg) & $1.66 \pm 0.11 \mathrm{~B}$ & $1.16 \pm 0.17 \mathrm{~A}$ & $1.9 \pm 0.25 \mathrm{C}$ & $1.16 \pm 0.16 \mathrm{~A}$ & $1.24 \pm 0.15 \mathrm{~A}$ \\
Pupal weight (mg) & $1.31 \pm 0.17 \mathrm{C}$ & $1.12 \pm 0.15 \mathrm{~B}$ & $1.09 \pm 0.13 \mathrm{~B}$ & $1.01 \pm 0.21 \mathrm{AB}$ & $0.93 \pm 0.14 \mathrm{~A}$ \\
\hline
\end{tabular}

Means within a row followed by the same letters are significantly different $\mathrm{P} \leq 0.05$ probability. 
The artificial diets were also tested on glass bottles to determine the suitable mass rearing environment (Fig. 4). The first day (Fig. 4A) and the $10^{\text {th }}$ day of the experiment (Fig. 4B) were shown. Larval feeding layers of the diets were clearly visible on the top of the diet (Fig. 4B) and mature larvae were usually seen on the sides of the bottles. The pupation of spotted-wing drosophila was occurred at the top of the bottles just underneath of the cotton balls used as a lid. Among the diets (Fig. 4B), larval development was faster on Diet II then Diet III and later Diet I (Control) which was similar as tested into petri dishes and presented in Table 2 .
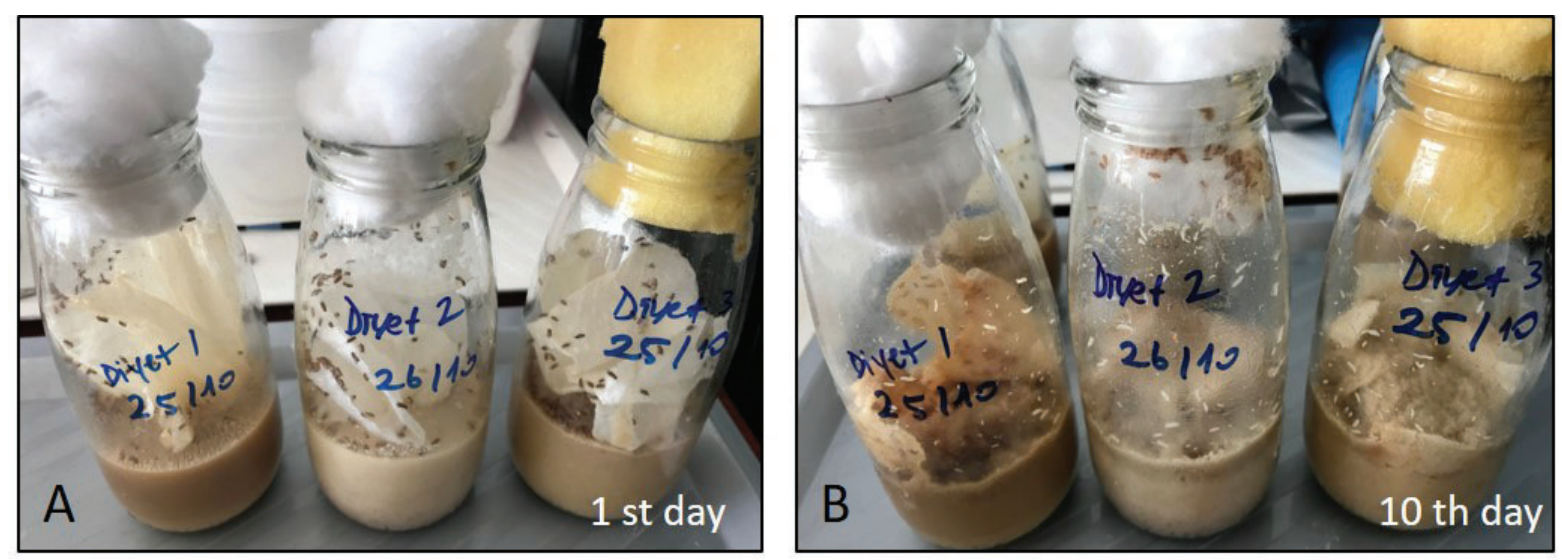

Fig. 4. A view of larval feeding on tested different diets in sterile glass bottles

Artificial diets are convenient to use rearing insects in the laboratory. Diet formulations that have been developed to increase insect's feeding and effectiveness of continuous rearing but they have not achieved the desired success (Dadd, 1985; Nation, 2016). In this study, different agar-based diets were tested for laboratory rearing of the spotted wing drosophila to determine a suitable diet with local ingredients. Faster larval development time (5.01 \pm 0.14 days), the percent of pupal recovery $(84.9 \pm 11.97)$ and number of emerged adults (62 \pm 7.64$)$ were observed on Diet II. Mature larvae preferred to pupate to sidewall of the bottles or inside the diet in petri dish. The average development time from egg to adult was 11.19 days on Diet II in this study. Similar results were observed on development time as 11 days (Schlesener et al., 2017) and 12 days (Matsubayashi et al., 1992) and 14.5 days (Emiljanowicz et al., 2014). The slight differences may due to temperature and diet compositions. It is known that Drosophila suzukii can easily adapt and develop faster on higher carbohydrate diet such as ripe berries and becomes adult stage earlier (Jaramillo et al., 2015). Diet II has sugar as an ingredient and provides enough carbohydrate source to support faster development of immature stages and slightly faster larval development compared to control diet (Schlesener et al., 2017).

\section{Conclusion}

The rearing method and tested diets were described in this study. Out of 5 diets, Diet II was suitable for the rearing of the spotted wing drosophila continuously in the laboratory. It provides sufficient larval development and growth. Mass rearing method using glass bottles tends to be more favorable having larger surface to walk off the diet for pupation also marked and removal of larvae or pupae for further studies.

\section{Acknowledgment}

This research work has been financially supported by Çanakkale Onsekiz Mart University, Scientific Research Council (Grant No: FHD-2018/Project no: 2586). The author thanks to Seda Yücel and Akın Kuyulu for their assistance in laboratory. 


\section{References}

Anonim, 2019. https://bdsc.indiana.edu/information/recipes/molassesfood.html Erişim tarihi: 13 Eylül 2019.

Beers, E.H., Van Steenwyk, R.A., Shearer, P.W., Coates, W.W., Grant, J.A., 2011. Development of Drosophila suzukii insecticide management programs for sweet cherry in the Western United States. Pest Management Sciences. 67 (11): 1386-1395.

Calabria, G., Máca, J., Bächli, G., Serra, L., Pascual, M., 2012. First records of the potential pest species Drosophila suzukii (Diptera:Drosophilidae) in Europe. Journal of Applied Entomology. 136(1-2): 139147. https://doi.org/10.1111/j.1439-0418.2010.01583.x

Cini, A., Ioriatti, C., Anfora, G., 2012. A review of the invasion of Drosophila suzukii in Europe and a draft research agenda for integrated pest management. Bulletin of Insectology. 65(1): 149-160.

Dadd, R.H., 1985. Nutrition: Organisms, pp. 313-390. In G A. Kerkut and L.I. Gilbert [Eds.], Comprehensive Insect Physiology, Biochemistry and Pharmacology, Vol. 4. Pergamon, Oxford. National Academy Press, Washington, DC.

Emiljanowicz, L.M., Ryan, G.D., Langille, A., Newman, J., 2014. Development, reproductive output and population growth of the fruit fly pest Drosophila suzukii (Diptera: Drosophilidae) on artificial diet. J. Econ. Entomol. 107: 1392-1398.

Jaramillo, S.L., Mehlferber, E., Moore, P.L., 2015. Life-history trade-offs under different larvla diets in Drosophila suzukii (Diptera:Drosophilidae). Physiological Entomology. 40:2-9.

Kanzawa, T. 1939. Studies on Drosophila suzukii Mats. Bulletin of the Yamanashi Agricultural Experiment Station, Abstract in Review of Applied Entomology. 29: 49s.

Kenis, M., Tonina, L., Eschen, R., Sluis, B. Van der. Sancassani, M., Mori, N. Haye, T., Helse, H., 2016. Noncrop plants used as hosts by Drosophila suzukii in Europe. Jornal of Pest Science. 89(3):735-748.

Lee, J.C., Dalton, D.T., Swoboda-Bhattarai, K.A., Bruck, D.J., Burrack, H.J., Strik, B.C., Woltz, J.M., Walton, V.M., 2016. Characterization and manipulation of fruit susceptibility to Drosophila suzukii. Pest Management Sciences. 89: 771-780.

Matsubayashi, H., Matsuda, M., Tomimura, Y., Shibata, M., Tobari, Y.N., 1992. Cytological mapping of Ommutants of Drosophila ananassae. Japanese Journal of Genetics. 67: 259-264.

Nation, J.L., 2016. Insect Physiology and Biochemistry. Third Edition. Taylor \&Francis Group, LLC. CRC Press. 644 pp.

Orhan, A., Aslantaş, R., Önder, B.Ş., Tozlu, G., 2016. First record of the invasive vinegar fly Drosophila suzukii (Matsumura) (Diptera: Drosophilidae) from Eastern Turkey. Turkish Journal of Zoology. 40: 290-293.

Raspi, A., Canale, A., Canovai, R., Conti, B., Loni, A., Strumia, F., 2011. Insetti delle aree protette del comune di San Giuliano Terme. Pisa, Italy: Felici Editore, San Giuliano Terme (İtalyanca).

Schlesener, D.C.H., Wollmann, J., Kruger, A.P., Martins, L.N., Geisler, F.C.S., Garcia, F.R.M., 2017. Rearing method for Drosophila suzukii and Zaprionus indianus (Diptera: Drosophilidae) on artificial culture media. Drosophila Information Service. 100: 185-189.

Schlesener, D. C.H., Wollmann, J., Kruger, A.P., Numes, A.M., Bernardi, D., Garcia. F.R.M., 2018. Biology and fertility life table of Drosophila suzukii on artificial diet. Entomologia Experimentalis et Applicata. 166:932-936. 